\title{
Minireview \\ Role of infiltrated leucocytes in tumour growth and spread
}

\author{
EY Lin' and JW Pollard*,I \\ 'Departments of Developmental and Molecular Biology and Obstetrics and Gynecology and Women's Health, Center for the Study of Reproductive \\ Biology and Women's Health and Albert Einstein Cancer Center, Albert Einstein College of Medicine, I 300 Morris Park Ave., Bronx, NY I046I, USA
}

Leucocytes are a major component of the tumour microenvironment. Recent studies have indicated that the infiltration and activity of these host cells are regulated by the tumour to promote its survival and progression. Through the production of an array of growth factors, proteases and angiogenic mediators, leucocytes in the tumour microenvironment promote tumour growth, angiogenesis and metastasis.

British Journal of Cancer (2004) 90, 2053 -2058. doi:I0.1038/sj.bjc.6601705 www.bjcancer.com

Published online 30 March 2004

(c) 2004 Cancer Research UK

Keywords: Leucocyte; tumour; progression; metastasis; angiogenesis

\section{TUMOUR-ASSOCIATED LEUCOCYTES}

The infiltration of leucocytes into solid tumours was remarked upon more than 100 years ago when it was suggested that they had a causal role in carcinogenesis. These infiltrates are now known to contain myeloid cells (neutrophils, dendritic cells, macrophages, eosinophils and mast cells) as well as lymphocytes. However, controversy remains over the relationship between these host cells and tumour progression. In the past, their presence has been construed as evidence for a host response against the growing tumour. This is because such immune functions were often observed in transplantable tumour models that by their nature represented a transplant that could elicit immune rejection despite being placed in immunocompromised hosts. However, it is becoming clear that tumours growing naturally are largely recognized as self and lack strong foreign antigens. Instead, they appear to have been selected to manipulate the host immune system to prevent rejection (Dunn et al, 2002) and use this system to facilitate their own growth and spread (Khong and Restifo, 2002). This lack of immune response has become particularly evident with the study of tumours induced by the restricted expression of oncogenes in transgenic mice where it has been established that tumour-associated leucocytes are often active participants in the neoplastic process. In addition, there is a growing body of clinical data on a wide range of solid tumour types that has correlated a high density of leucocytic infiltration with poor outcome (Coussens and Werb, 2001, 2002). Furthermore, it has be recognised that cells containing DNA alterations caused by viral or chemical carcinogens do not progress to become cancerous until they are exposed to a second type of stimulus that often includes chronic irritants or inflammatory agents (Coussens and Werb, 2002). For example, an inflammatory response is required to induce cancers in chickens infected with the potent oncogenic Rous Sarcoma virus despite it carrying the v-src oncogene that alone is competent to transform fibroblasts in

*Correspondence: Dr JW Pollard; E-mail: pollard@aecom.yu.edu Received I5 December 2003; accepted 19 January 2004; published online 30 March 2004 culture (Sieweke et al, 1989). This view of the role of leucocytes in facilitating cancer progression has been further enhanced by the realisation that many cancers are caused or promoted by infectious or other agents that induce chronic inflammation (Coussens and Werb, 2002).

Under normal physiological circumstances, leucocytes are recruited in response to wounding, inflammatory or pathogenic stimuli. They are attracted by the local synthesis of chemokines (chemoattractive cytokines), cytokines and growth factors as well as products of tissue breakdown. These are all part of a signalling system that involves recognition of the pathological state, organisation of an appropriate cellular response and suppression of this response once the situation is resolved. During cutaneous wound healing, these processes require epithelial cell proliferation and migration, angiogenesis and tissue remodelling (Nathan, 2002). In tumours, it is thought that similar chemoattractive factors are also responsible for the recruitment of leucocytes and that these cells play roles comparable to those observed during wound healing. However, because of the accumulation of intrinsic mutations the epithelial cells have lost positional identity and consequently do not stop growing and migrating on cue. Instead, they send out continuous signals that recruit leucocytes to continue to support the tumor's development. This concept has led to the rubric that tumours are 'wounds that never heal' (Balkwill and Mantovani, 2001).

Several steps are crucial for a tumour to become metastatic. Tumour cells need to be able to break out of their confining basement membranes in order to enter the extracellular matrix and circulation. These processes require the proteolytic breakdown of basement membranes, changes in epithelial cell adhesion, migration and the suppression of ankoisis. They are matched in the surrounding stroma with angiogenesis as well as the frequent recruitment of leucocytes. Angiogenesis, known to be the crucial process for tumour progression by providing oxygen and nutrients and removal of waste products, as well as, providing an expanding endothelial surface for the tumour cells to enter the circulation, also involves degradation of basement membranes followed by migration of endothelial cells into the tumour stroma (Folkman, 2002). Recent studies have shown that the tumour-associated leucocytes produce factors that promote all these steps associated 
with malignancy within tumours (Ribatti et al, 2001). This review will focus on the evidence that members of the myeloid lineage, particularly macrophages, neutrophils and mast cells, can facilitate tumour progression.

\section{Macrophages}

Macrophages derived from circulating monocytes represent a major component of the infiltrated leucocytic population in the tumour microenvironment. These cells have a wide range of functions in immunity, during development and in tissue repair. They can adopt a particular phenotype according to the demand and produce many factors ranging from chemokines, cytokines, and proteases, to angiogenic and growth factors. They therefore appear to be the 'jack-of all trades' of the myeloid lineage. Of all the cells of the myeloid lineage, the evidence is strongest in support of a positive impact of macrophages on tumour progression. For example, in greater than $80 \%$ of clinical studies, an increase in tumour-associated macrophages (TAMs) density is correlated with poor prognosis, with less than $10 \%$ of studies showing the converse (Bingle et al, 2002). Similarly, overexpression of macrophage chemoattractants within tumours has also been shown to correlate with poor prognosis (Leek and Harris, 2002). One such example is colony stimulating factor-1 (CSF-1 ormacrophage CSF), a macrophage growth factor as well as a potent macrophage chemoattractant (Lin et al, 2002). Overexpression of CSF-1 correlates with poor prognosis in human breast, ovarian endometrial and prostatic carcinomas (Kacinski, 1997). In breast cancers, this overexpression correlates with a strong leucocytic infiltration in over $95 \%$ of cases (Scholl et al, 1994). Similarly, the $\mathrm{CC}$ chemokine ligand $2 \mathrm{CCL} / \mathrm{MCP}-1(\mathrm{MCP}=$ monocyte chemoattractant protein 1) has been identified as a major chemokine for macrophages recruitment in several human tumours, including the bladder (Amann et al, 1998), cervix (Riethdorf et al, 1996), ovary (Negus et al, 1995), lung (Arenberg et al, 2000) and breast (Valkovic et al, 1998; Ueno et al, 2000). The level of CCL2/MCP-1 expression is correlated with the increased infiltration of macrophage (Ueno et al, 2000) and the grade of tumour (Amann et al, 1998; Valkovic et al, 1998). Although both CSF-1 and CCL-2 can be targeted to the tumour cells themselves, the strong correlation of overexpression of these macrophage chemoattractants with macrophage recruitment and poor prognosis suggests that TAMs can play a major role in the progression of tumours to metastasis.

Several experiments have supported the role of macrophages in tumour progression. We have observed that in a Polyoma Middle $\mathrm{T}$ antigen-induced mouse model of breast cancer (PyMT), an increase of macrophage infiltration at the primary tumour site occurred immediately before the onset of malignant transition (Figure 1) (Lin et al, 2001). Using genetic approaches, we demonstrated that depletion of CSF-1 in this model markedly decreased the infiltration of macrophages at the tumor site and this correlated with a significant delay of tumour progression to metastasis. In contrast, overexpression of CSF-1 in the tumour dramatically increased the macrophage density in the primary tumour and this was correlated with an accelerated malignant switch (Lin et al, 2001). Similarly, removal of CSF-1 from transplanted tumours also resulted in an impairment of growth with extensive necrosis and poor vascularisation, phenotypes that could be reversed by treatment of the mice with CSF-1 (Nowicki et al, 1996). These studies have provided strong evidence that TAMs promote the tumour progression to malignancy. This conclusion was enhanced by the observations that treatment of mice that had been xenotransplanted with either a human colonic or embryonic tumour with antisense oligonucleotides directed against mouse CSF-1 reduced tumour growth and prolonged survival. This was associated with a reduced serum concentration of CSF-1 and a decreased TAM density. Since mouse CSF-1 does not stimulate the human receptor, these data argue for the effects

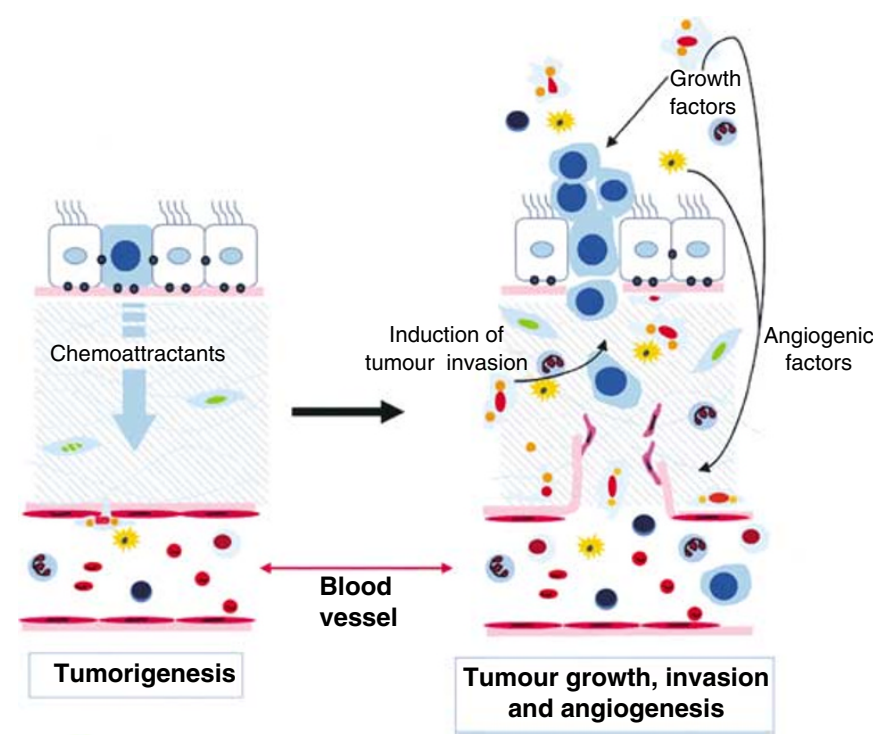

\begin{tabular}{|llll|}
\hline$\div$ Macrohage & Mast cell & Monocyte \\
- Fibroblast & 6 Granulocyte & Lymphocyte \\
\hline
\end{tabular}

Figure I Leucocytic infiltration promotes tumour progression to malignancy. In a manner similar to wounded tissues, solid tumours induce a local 'inflammatory response' by attracting leucocytes into its microenvironment. Such an infiltration consists of multiple cell types of which cells of the myeloid lineage are the major component. Leucocytes in such 'inflammatory sites' produce an array of growth and angiogenic factors, proteases and mutagenic factors that promote tumour growth, invasion and angiogenesis. However, different from its physiological counterpart whose inflammation ceases when the wound has healed, tumour-induced inflammation persists and eventually leads to tumour progression and metastasis.

of the CSF-1 antisense molecules to be mediated through the reduction in TAMs (Aharinejad et al 2002).

The evidence from both clinical and experimental studies supports the view that, in most cases, TAMs facilitate tumour progression and metastasis. The mechanism(s) macrophages used to promote tumour progression are still unknown; however, it has been proposed that macrophages may promote tumour growth and angiogenesis through the production of growth factors and angiogenic inducers such as Epidermal Growth Factor (EGF), vascular endothelial growth factor (VEGF), tumour necrosis factor (TNF $\alpha$ ) and Thymidine Phosphorylase (TP) (Xiong et al, 1998; Leek and Harris, 2002). Macrophages also indirectly enhance blood vessel formation by possessing a procoagulant activity through fibrin deposition (Mantovani et al, 1992). In addition, many macrophages produced factors, proteases and protease activators such as transforming growth factor- $\beta(\operatorname{TGF} \beta)$, platelet-derived growth factor, interleukin-6 (IL-6), urokinase plasminogen activator and Tissue-type Plasminogen Activator (t-PA) that may cause degradation of extracellular matrix to facilitate the tumour cell invasion and migration and induce angiogenesis (Egami et al, 2003; Eubank et al, 2003; Hildenbrand et al, 1995; Klimetzek and Sorg, 1977). Moreover, TAMs contribute greatly to the growth of the tumour by producing proangiogenic and tumour-stimulating chemokines such as CCR2 ligands (Vicari and Caux, 2002).

Macrophages can display tumour cytoxicity and can potentially present tumour antigens to induce specific immune reaction against tumours. However, these cells are believed to have primarily a protumour function since both tumours and TAMs produce potent immunomodulating agents that suppress macrophage tumoricidal activity. Such tumour-produced molecules, including IL-4, IL-6, IL-10, CSF-1, TGF $\beta$ and prostaglandin E2 
(PGE2), and TAM-produced factors such as IL-10 and PGE2, contribute to the general immunosuppression of the host as well as the antitumour activity of macrophages (Elgert et al, 1998; Mytar et al, 2003). Although infiltration of macrophages is usually correlated with poor outcome (Hamada et al, 2002), recent studies have also shown that infiltrated macrophages may have an anti tumour action in colorectal cancer (Nakayama et al, 2002; Noguchi et al, 2003). These observations indicate that the microenvironment of different type of tumours might alter the activities of infiltrated leucocytes from tumour promotion to tumour rejection. This has led to the idea of tumour-educated macrophages whose functions are modified by the local cytokine/chemokine environment (Pollard, 2004). In most cases, this enhances tumour development and directs the local immune system away for an antitumour response (Mantovani et al, 2002).

Dendritic cells (DCs) also play an important role in both the activation of antigen-specific immunity and the maintenance of tolerance, providing a link between innate and adaptive immunity. Several clinical studies have reported the presence of DC within human tumours such as the stomach, colon, prostate, kidney, thyroid, breast and melanoma (Tsujitani et al, 1990; Enk et al, 1997; Troy et al, 1998; Bell et al, 1999; Lespagnard et al, 1999; Schwaab et al, 1999, 2001; Scarpino et al, 2000). However, the effect of such an infiltration in tumour progression is still not clear. Some of these studies have shown that the infiltration of DC was associated with enhanced patient survival (lung), whereas others showed that DC present in tumour either were minimally activated (Tsujitani et al, 1990; Troy et al, 1998), had no correlation with metastasis-free or overall survival of the patients (Lespagnard et al, 1999) or were converted to 'silencers' of antitumour immune responses by tumour-produced factors (Enk et al, 1997). In addition, studies have reported that patients with a variety of cancers have impaired function of DCs, indicating a systemic effect of the tumours on DCs (Almand et al, 2000). Moreover, recent studies have suggested that, instead of initiating immune responses against tumours, DC in the tumour microenvironment may have the ability to turn off the responding $\mathrm{T}$ cells and induce tolerance (Hackstein et al, 2001; Vicari and Caux, 2002). The relationship between host DC, lymphocytes and tumour in the process of 'tumour escape' from the host immune system has been reviewed in detail recently and will not be discussed here (Khong and Restifo, 2002; Hanahan et al, 2003). Nevertheless, the evidence on balance suggests that tumours promote the suppression of these potentially damaging cells while enhancing the trophic nature of macrophages. The hope, however, is that therapeutic modulation of this environment locally could result in TAMs that are tumoricidal and that together with properly matured DCs would present antigens to infiltrating $\mathrm{T}$ cells with the consequent rejection of the tumour (Dranoff, 2004).

\section{Mast cells}

An infiltration of mast cells has been found in a variety of human cancers, including non-small-cell lung cancer (Shijubo et al, 2003), breast cancer (Kankkunen et al, 1997), colorectal cancer (Lachter et al, 1995), basal cell carcinoma (Yamamoto et al, 1997) and pulmonary adenocarcinoma (Imada et al, 2000). The accumulation of mast cells has been associated with enhanced growth and invasion of several human cancers (Ribatti et al, 2001). However, there are other studies in colorectal cancer where their presence is indicative of improved prognosis (Nielsen et al, 1999). Initial studies using animal models have shown that increasing mast cell density in tumour promoted tumour growth (Roche, 1985), whereas reducing their number inhibited tumour growth and angiogenesis (Starkey et al, 1988). The role of inflammatory mast cells in tumour progression of squamous epithelial carcinogenesis was also illustrated recently (Coussens et al, 1999). Furthermore, Schwann cell tumours caused by inherited mutations in the NF1 gene do not form in mouse models unless the surrounding stromal cells are at least heterozygous for the mutation. These tumours are highly populated with mast cells and it seems likely that a haploinsufficiency of NFI in these cells is the cause of the tumour formation (Zhu et al, 2002).

The best known role that mast cells plays in tumour progression is their ability to induce tumour angiogenesis (Hiromatsu and Toda, 2003). Activated mast cells produce a variety of angiogenic growth factors, including VEGF, basic fibroblast growth factor, IL8 and TNF $\alpha$ (Meininger and Zetter, 1992; Qu et al, 1995; Hiromatsu and Toda, 2003). In addition, they can produce specific angiogenic mediators including histamine and heparin, which can stimulate endothelial cell proliferation and may contribute to the hyperpermeable nature of newly formed microvessels during pathological angiogenesis (Ribatti et al, 2001), and a variety of proteases, particularly MMP9, which are involved in angiogenesis. How tumour cells regulate the infiltration and activation of mast cells is still not fully understood. However, several types of tumours produce stem cell factor that may have functions in mast cell migration, proliferation and activation (Turner et al, 1992). In addition to the promotion of angiogenesis, the activated mast cells are a rich source of cytokines and chemokines such as IL-1, IL-3, IL-4, IL-8, granulocyte-macrophage colony-stimulating factor, $\mathrm{TNF} \alpha$, interferon- $\gamma$ (IFN $\gamma$ ), CCL-2, Macrophage Inflammatory Protein MIP- $1 \alpha$ and $\beta$, many of which can contribute to the tumour microenvironment by enhancing tumour cell growth and invasion either directly or through intermediaries such as macrophages (Burd et al, 1989; Selvan et al, 1994).

\section{Neutrophils}

The role of neutrophils in tumour progression is still controversial. During immune responses, they are among the first cells to arrive at sites of infection where they are highly bactericidal. They are also involved in cell killing during graft rejection and thus they might be considered as potential antitumour cells. However, clinical studies have been contradictory. The presence of increased numbers of tumour-infiltrating neutrophils was linked to poorer outcome in patients with adenocarcinoma of the bronchioloalveolar carcinoma subtype (Bellocq et al, 1998), whereas studies of gastric carcinoma suggested that neutrophil infiltration correlated with good prognosis (Caruso et al, 2002). It has been reported that tumours prolong alveolar neutrophil survival through the production of soluble factors (Wislez et al, 2001). Using transplantable tumour models, studies have shown that tumour-associated neutrophils were involved in tumour angiogenesis by the production of proangiogenic factors such as VEGF and IL-8 (Schaider et al, 2003), proteases such as matrix metalloproteinases (Shamamian et al, 2001) and elastases (Iwatsuki et al, 2000; Scapini et al, 2002). In addition, studies using animal models have also shown that neutrophils may contribute to genetic instability in tumours (Haqqani et al, 2000).

Furthermore, neutrophil-recruiting cytokines such as GRO (IL-8 homologues) may also directly stimulate tumour proliferation in melanoma (Haghnegahdar et al, 2000). Taken together, an environment that recruits neutrophils might enhance angiogenesis, promote tumour invasion and stimulate growth.

\section{CONCLUSION}

Solid tumours are not just composed of malignant cells, but are complex microcosms of many cell types including a wide range of haematopoietic cells. The evidence described above suggests that cells of the myeloid lineages, particularly macrophages, mast cells and neutrophils, on balance play an active role in enhancing tumour progression and metastatic capacity. This is through their ability to promote angiogenesis and tissue remodelling as well as 
direct effects on epithelial cell viability, growth and migration. In wound healing or in response to an inflammatory stimulus, a similar panoply of cells is recruited. Sentinel cells, particularly macrophages and mast cells that send out chemotactic signals that in the first wave, bringing in neutrophils and monocytes, initiate this recruitment. These not only eliminate pathogens but also effect tissue repair, a process that involves angiogenesis and an induction of vascular permeability, tissue remodelling and the migration and proliferation of epithelial cells. These events are coordinated by a sophisticated and as yet, not understood language of soluble mediators involving cytokines, chemokines and growth factors.

Similarly, during development, myeloid cells, particularly macrophages, play an important role in tissue formation and their absence often results in attenuated poorly formed structures in tissues as wide ranging as bone, skin and mammary gland (Pollard, 2004). It would seem highly likely that tumours send out signals similar to those found in normal physiology to recruit myeloid cells and instruct them to perform similar tasks in tissue remodelling. However, unlike their normal counterparts, the epithelial tumour cells do not stop growing in response to positional cues and continuously send out signals to demand help from the invading myeloid cells.

The tumour microenvironment also educates those invading cells to promote epithelial growth, viability, motility and invasion. Thus, it is noticeable in many tumour types that there are dense lymphocytic infiltration sites adjacent to areas of basement membrane breakdown and tumour invasion (Figure 1). In our studies of the PyMT oncoprotein-induced mammary cancers, these sites marked the transition from nonmalignant to malignant tumours, suggesting that they had a causal role in this process. Furthermore, it appears in this model that macrophages are the sentinel cells that recruit other myeloid cells. This was confirmed by the ablation of macrophages that stopped the infiltration sites from occurring and which resulted in an inhibition of metastatic capacity (Lin et al, 2001; 2003). The challenge, therefore, will be to define whether there are unique phenotypes of these tumourassociated myeloid cells that can distinguish them from those involved in immune or tissue repair responses that could be a target for therapeutic agents. In addition, it will be important to understand the cytokine network in the tumour microenvironment that promotes tumour progression so that it can be tilted away from eliciting tropic activities to one that enhances the detection of the tumours as an aberrant state with the resultant suppression of its development and perhaps immunological rejection of the tumour.

\section{Note added in proof}

Ablation of macrophage recruitment in transplantable breast cancers by a chemokine receptor antagonist significantly inhibited tumour development (Robinson et al, 2003). Similarly, inhibition of MMP9 production in tumour-associated macrophages by a hypomorphic Ets-2 mutation also inhibited tumour development in the PyMT mouse model of breast cancer (Man et al, 2003). These data confirms the involvement of macrophages in tumour development in mouse models.

\section{REFERENCES}

Aharinejad S, Abraham D, Paulus P, Abri H, Hofmann M, Grossschmidt K, Schafer R, Stanley ER, Hofbauer R (2002) Colony-stimulating factor-1 antisense treatment suppresses growth of human tumor xenografts in mice. Cancer Res 62: 5317-5324

Almand B, Resser JR, Lindman B, Nadaf S, Clark JI, Kwon ED, Carbone DP, Gabrilovich DI (2000) Clinical significance of defective dendritic cell differentiation in cancer. Clin Cancer Res 6: 1755-1766

Amann B, Perabo FG, Wirger A, Hugenschmidt H, Schultze-Seemann W (1998) Urinary levels of monocyte chemo-attractant protein-1 correlate with tumour stage and grade in patients with bladder cancer. $\mathrm{Br} \mathrm{J}$ Urol 82: $118-121$

Arenberg DA, Keane MP, DiGiovine B, Kunkel SL, Strom SR, Burdick MD, lannettoni MD, Strieter RM (2000) Macrophage infiltration in human non-small-cell lung cancer: the role of CC chemokines. Cancer Immunol Immunother 49: 63-70

Balkwill F, Mantovani A (2001) Inflammation and cancer: back to Virchow? Lancet 357: $539-545$

Bell D, Chomarat P, Broyles D, Netto G, Harb GM, Lebecque S, Valladeau J, Davoust J, Palucka KA, Banchereau J (1999) In breast carcinoma tissue, immature dendritic cells reside within the tumor, whereas mature dendritic cells are located in peritumoral areas. J Exp Med 190: $1417-1426$

Bellocq A, Antoine M, Flahault A, Philippe C, Crestani B, Bernaudin JF, Mayaud C, Milleron B, Baud L, Cadranel J (1998) Neutrophil alveolitis in bronchioloalveolar carcinoma: induction by tumor-derived interleukin-8 and relation to clinical outcome. Am J Pathol 152: 83-92

Bingle L, Brown NJ, Lewis CE (2002) The role of tumour-associated macrophages in tumour progression: implications for new anticancer therapies. J Pathol 196: 254-265

Burd PR, Rogers HW, Gordon JR, Martin CA, Jayaraman S, Wilson SD Dvorak AM, Galli SJ, Dorf ME (1989) Interleukin 3-dependent and -independent mast cells stimulated with IgE and antigen express multiple cytokines. J Exp Med 170: 245 - 257

Caruso RA, Bellocco R, Pagano M, Bertoli G, Rigoli L, Inferrera C (2002) Prognostic value of intratumoral neutrophils in advanced gastric carcinoma in a high-risk area in northern Italy. Mod Pathol 15: $831-837$

Coussens LM, Raymond WW, Bergers G, Laig-Webster M, Behrendtsen O, Werb Z, Caughey GH, Hanahan D (1999) Inflammatory mast cells upregulate angiogenesis during squamous epithelial carcinogenesis. Genes Dev 13: $1382-1397$

Coussens LM, werb Z (2001) Inflammatory cells and cancer: think different!. J Exp Med 193: F23 - F26

Coussens LM, Werb Z (2002) Inflammation and cancer. Nature 420: 860 - 867

Dranoff G (2004) Cytokines in cancer pathogenesis and cancer theraphy. Nat Rev Cancer 4: 11-22

Dunn GP, Bruce AT, Ikeda H, Old LJ, Schreiber RD (2002) Cancer immunoediting: from immunosurveillance to tumor escape. Nat Immunol 3: $991-998$

Egami K, Murohara T, Shimada T, Sasaki K, Shintani S, Sugaya T, Ishii M, Akagi T, Ikeda $\mathrm{H}$, Matsuishi $\mathrm{T}$, Imaizumi $\mathrm{T}$ (2003) role of host angiotensin II type 1 receptor in tumor angiogenesis and growth. J Clin Invest 112: $67-75$

Elgert K, Alleva D, Mullins D (1998) Tumor-induced immune dysfunction:the macrophage connection. J Leukoc Biol 64: 275-290

Enk AM, Jonuleit H, Saloga J, Knop J (1997) Dendritic cells as mediators of tumor-induced tolerance in metastatic melanoma. Int $J$ Cancer 73: 309-316

Eubank TD, Galloway M, Montague CM, Waldman WJ, Marsh CB (2003) $\mathrm{M}-\mathrm{CSF}$ induces vascular endothelial growth factor production and angiogenic activity from human monocytes. J Immunol 171: 2637-2643

Folkman J (2002) Role of angiogenesis in tumor growth and metastasis. Semin Oncol 29: $15-18$

Hackstein H, Morelli AE, Thomson AW (2001) Designer dendritic cells for tolerance induction: guided not misguided missiles. Trends Immunol 22: $437-442$

Haghnegahdar H, Du J, Wang D, Stricter RM, Burdick MD, Nanney LB, Cardwell N, Luan J, Shattuck-Brandt R, Richmond A (2000) The tumorigenic and angiogenic effects of MGSA/GRO proteins in melanoma. J Leukoc Biol 67: 53-62

Hamada I, Kato M, Yamasaki T, Iwabuchi K, Watanabe T, Yamada T, Itoyama S, Ito H, Okada K (2002) Clinical effects of tumor-associated macrophages and dendritic cells on renal cell carcinoma. Anticancer Res 22: $4281-4284$ 
Hanahan D, Lanzavecchia A, Mihich E (2003) Fourteenth Annual Pezcoller Symposium: the novel dichotomy of immune interactions with tumors. Cancer Res 63: 3005-3008

Haqqani AS, Sandhu JK, Birnboim HC (2000) Expression of interleukin-8 promotes neutrophil infiltration and genetic instability in mutatect tumors. Neoplasia 2: 561-568

Hildenbrand R, Dilger I, Horlin A, Stutte HJ (1995) Urokinase and macrophages in tumour angiogenesis. Br J Cancer 72: 818-823

Hiromatsu Y, Toda S (2003) Mast cells and angiogenesis. Microsc Res Tech 60: $64-69$

Imada A, Shijubo N, Kojima H, Abe S (2000) Mast cells correlate with angiogenesis and poor outcome in stage I lung adenocarcinoma. Eur Respir J 15: 1087 - 1093

Iwatsuki K, Kumara E, Yoshimine T, Nakagawa H, Sato M, Hayakawa T (2000) Elastase expression by infiltrating neutrophils in gliomas. Neurol Res 22: $465-468$

Kacinski BM (1997) CSF-1 and its receptor in breast carcinomas and neoplasms of the female reproductive tract. Mol Reprod Dev 46: $71-74$

Kankkunen JP, Harvima IT, Naukkarinen A (1997) Quantitative analysis of tryptase and chymase containing mast cells in benign and malignant breast lesions. Int J Cancer 72: 385-388

Khong HT, Restifo NP (2002) Natural selection of tumor variants in the generation of "tumor escape" phenotypes. Nat Immunol 3: 999- 1005

Klimetzek V, Sorg C (1977) Lymphokine-induced secretion of plasminogen activator by murine macrophages. Eur J Immunol 7: 185-187

Lachter J, Stein M, Lichtig C, Eidelman S, Munichor M (1995) Mast cells in colorectal neoplasias and premalignant disorders. Dis Colon Rectum 38: $290-293$

Leek RD, Harris AL (2002) Tumor-associated macrophages in breast cancer. J Mamm Gland Biol Neoplasia 7: 177-189

Lespagnard L, Gancberg D, Rouas G, Leclercq G, de Saint-Aubain Somerhausen N, Di Leo A, Piccart M, Verhest A, Larsimont D (1999) Tumor-infiltrating dendritic cells in adenocarcinomas of the breast: a study of 143 neoplasms with a correlation to usual prognostic factors and to clinical outcome. Int J Cancer 84: 309-314

Lin EY, Gouon-Evans V, Nguyen AV, Pollard JW (2002) The macrophage growth factor, CSF-1, in mammary gland development and cancer. J Mamm Gland Dev Neoplasia 7: 147-162

Lin EY, Jones JG, Li P, Zhu L, Whitney KD, Muller WJ, Pollard JW (2003) Progression to malignancy in the polyoma middle $\mathrm{T}$ oncoprotein mouse breast cancer model provides a reliable model for human diseases. Am J Pathol 163: 2113-2126

Lin EY, Nguyen AV, Russell RG, Pollard JW (2001) Colony-stimulating factor 1 promotes progression of mammary tumors to malignancy. J Exp Med 193: 727-740

Mantovani A, Bottazzi B, Colotta F, Sozzani S, Ruco L (1992) The origin and function of tumor-associated macrophages. Immunol today 13: $265-270$

Man AK, Young LJT, Tynan JA, Lesperance J, Egeblad M, Werb Z, Hauser CA, Muller WJ, Cardiff RD, Oshima RG (2003) Ets2-dependent stromal regulation of mouse mammary tumors. Molecular and Cellular Biology 23: $8614-8625$

Meininger CJ, Zetter BR (1992) Mast cells and angiogenesis. Semin Cancer Biol 3: $73-79$

Mantovani A, Sozzani S, Locati M, Allavena P, Sica A (2002) Macrophage polarization: tumor-associated macrophages as a paradigm for polarized M2 mononuclear phagocytes. Trends in Immunology 23: $549-555$

Mytar B, Woloszyn M, Szatanek R, Baj-Krzyworzeka M, Siedlar M, Ruggiero I, Wieckiewicz J, Zembala M (2003) Tumor cell-induced deactivation of human monocytes. J Leukoc Biol 74: 1094-1101

Nakayama Y, Nagashima N, Minagawa N, Inoue Y, Katsuki T, Onitsuka K, Sako T, Hirata K, Nagata N, Itoh H (2002) Relationships between tumorassociated macrophages and clinicopathological factors in patients with colorectal cancer. Anticancer Res 22: 4291-4296

Nathan C (2002) Points of control in inflammation. Nature 420: $846-852$

Negus RP, Stamp GW, Relf MG, Burke F, Malik ST, Bernasconi S, Allavena P, Sozzani S, Mantovani A, Balkwill FR (1995) The detection and localization of monocyte chemoattractant protein-1 (MCP-1) in human ovarian cancer. J Clin Invest 95: 2391-2396

Nielsen HJ, Hansen U, Christensen IJ, Reimert CM, Brunner N, Moesgaard F (1999) Independent prognostic value of eosinophil and mast cell infiltration in colorectal cancer tissue. J Pathol 189: 487-495
Noguchi T, Wada S, Takeno S, Moriyama H, Kimura Y, Uchida Y (2003) Lymph node metastasis could be predicted by evaluation of macrophage infiltration and hsp70 expression in superficial carcinoma of the esophagus. Oncol Rep 10: $1161-1164$

Nowicki A, Szenajch J, Ostrowska G, Wojtowicz A, Wojtowicz K, Kruszewski AA, Maruszynski M, Aukerman SL, Wiktor-Jedrzejczak W (1996) Impaired tumor growth in colony-stimulating factor 1 (CSF-1)deficient/macrophage-deficient op/op mouse: evidence for a role of CSF1-dependent macrophages in formation of tumor stroma. Int J Cancer 65: $112-119$

Pollard JW (2004) Tumor educated macrophages promote tumor progression and metastasis. Nat Rev Cancer 4: 71-78

Qu Z, Liebler JM, Powers MR, Galey T, Ahmadi P, Huang XN, Ansel JC, Butterfield JH, Planck SR, Rosenbaum JT (1995) Mast cells are a major source of basic fibroblast growth factor in chronic inflammation and cutaneous hemangioma. Am J Pathol 147: 564-573

Ribatti D, Vacca A, Nico B, Crivellato E, Roncali L, Dammacco F (2001) The role of mast cells in tumour angiogenesis. Br J Haematol 115: 514-521

Riethdorf L, Riethdorf S, Gutzlaff K, Prall F, Loning T (1996) Differential expression of the monocyte chemoattractant protein-1 gene in human papillomavirus-16-infected squamous intraepithelial lesions and squamous cell carcinomas of the cervix uteri. Am J Pathol 149: 1469-1476

Robinson SC, Scott KA, Wilson JL, Thompson RG, Proudfoot AEI, Balkwill FR (2003) A chemokine receptor antagonist inhibits experimental breast tumor growth. Cancer Res 63: 8360-8365

Roche WR (1985) Mast cells and tumour angiogenesis: the tumor-mediated release of an endothelial growth factor from mast cells. Int J Cancer 36: $721-728$

Scapini P, Nesi L, Morini M, Tanghetti E, Belleri M, Noonan D, Presta M, Albini A, Cassatella MA (2002) Generation of biologically active angiostatin kringle 1-3 by activated human neutrophils. J Immunol 168: $5798-5804$

Scarpino S, Stoppacciaro A, Ballerini F, Marchesi M, Prat M, Stella MC, Sozzani S, Allavena P, Mantovani A, Ruco LP (2000) Papillary carcinoma of the thyroid: hepatocyte growth factor (HGF) stimulates tumor cells to release chemokines active in recruiting dendritic cells. Am J Pathol 156: $831-837$

Schaider H, Oka M, Bogenrieder T, Nesbit M, Satyamoorthy K, Berking C, Matsushima K, Herlyn M (2003) Differential response of primary and metastatic melanomas to neutrophils attracted by IL-8. Int J Cancer 103: $335-343$

Scholl SM, Pallud C, Beuvon F, Hacene K, Stanley ER, Rohrschneider LR, Tang R, Pouillart P, Lidereau R (1994) Anti-colony-stimulating factor- 1 antibody staining in primary breast adenocarcinomas correlates with marked inflammatory cell infiltrates and prognosis. J Nat Cancer Inst 86: $120-126$

Schwaab T, Schned AR, Heaney JA, Cole BF, Atzpodien J, Wittke F, Ernstoff MS (1999) In vivo description of dendritic cells in human renal cell carcinoma. J Urol 162: 567-573

Schwaab T, Weiss JE, Schned AR, Barth Jr RJ (2001) Dendritic cell infiltration in colon cancer. J Immunother 24: $130-137$

Selvan RS, Butterfield JH, Krangel MS (1994) Expression of multiple chemokine genes by a human mast cell leukemia. J Biol Chem 269: $13893-13898$

Shamamian P, Schwartz JD, Pocock BJ, Monea S, Whiting D, Marcus SG, Mignatti P (2001) Activation of progelatinase A (MMP-2) by neutrophil elastase, cathepsin G, and proteinase-3: a role for inflammatory cells in tumor invasion and angiogenesis. J Cell Physiol 189: 197-206

Shijubo N, Kojima H, Nagata M, Ohchi T, Suzuki A, Abe S, Sato N (2003) Tumor, angiogenesis of non-small cell lung cancer. Microsc Res Tech 60: $186-198$

Sieweke MH, Stoker AW, Bissell MJ (1989) Evaluation of the cocarcinogenic effect of wounding in Rous sarcoma virus tumorigenesis. Cancer Res 49: 6419-6424

Starkey JR, Crowle PK, Taubenberger S (1988) Mast-cell-deficient W/Wv mice exhibit a decreased rate of tumor angiogenesis. Int $J$ Cancer 42: $48-52$

Troy A, Davidson P, Atkinson C, Hart D (1998) Phenotypic characterisation of the dendritic cell infiltrate in prostate cancer. J Urol 160: 214-219

Tsujitani S, Kakeji Y, Watanabe A, Kohnoe S, Maehara Y, Sugimachi K (1990) Infiltration of dendritic cells in relation to tumor invasion and lymph node metastasis in human gastric cancer. Cancer 66: 2012-2016

Turner AM, Zsebo KM, Martin F, Jacobsen FW, Bennett LG, Broudy VC (1992) Nonhematopoietic tumor cell lines express stem cell factor and display c-kit receptors. Blood 80: 374-381 
Ueno T, Toi M, Saji H, Muta M, Bando H, Kuroi K, Koike M, Inadera H, Matsushima K (2000) Significance of macrophage chemoattractant protein-1 in macrophage recruitment, angiogenesis, and survival in human breast cancer. Clin Cancer Res 6: 3282-3289

Valkovic T, Lucin K, Krstulja M, Dobi-Babic R, Jonjic N (1998) Expression of monocyte chemotactic protein-1 in human invasive ductal breast cancer. Pathol Res Pract 194: 335-340

Vicari AP, Caux C (2002) Chemokines in cancer. Cytokine Growth Factor Rev 13: $143-154$

Wislez M, Fleury-Feith J, Rabbe N, Moreau J, Cesari D, Milleron B, Mayaud C, Antoine M, Soler P, Cadranel J (2001) Tumor-derived granulocyte-macrophage colony-stimulating factor and granulocyte

colony-stimulating factor prolong the survival of neutrophils infiltrating bronchoalveolar subtype pulmonary adenocarcinoma. Am J Pathol 159: $1423-1433$

Xiong M, Elson G, Legarda D, Leibovich SJ (1998) Production of vascular endothelial growth factor by murine macrophages: regulation by hypoxia, lactate, and the inducible nitric oxide synthase pathway. $A m \mathrm{~J}$ Pathol 153: 587-598

Yamamoto T, Katayama I, Nishioka K (1997) Expression of stem cell factor in basal cell carcinoma. Br J Dermatol 137: 709-713

Zhu Y, Ghosh P, Charnay P, Burns DK, Parada LF (2002) Neurofibromas in NF1: Schwann cell origin and role of tumor environment. Science 296: $920-922$ 